DIGITAL COMMONS
@ UNIVERSITY OF SOUTH FLORIDA

Journal of African Conflicts and

Peace Studies

January 2021

\title{
An Evaluation of Peace Building Strategies in Southwestern Nigeria: Quantitative and Qualitative Examples
}

\author{
Kazeem Oyedele Lamidi \\ Obafemi Awolowo University, Ile-Ife, akandekande@oauife.edu.ng
}

Follow this and additional works at: https://digitalcommons.usf.edu/jacaps

Part of the African Studies Commons, Development Studies Commons, Peace and Conflict Studies Commons, Policy Design, Analysis, and Evaluation Commons, Social Policy Commons, and the Social Work Commons

\section{Recommended Citation}

Lamidi, Kazeem Oyedele (2021) "An Evaluation of Peace Building Strategies in Southwestern Nigeria: Quantitative and Qualitative Examples," Journal of African Conflicts and Peace Studies: Vol. 4: Iss. 2, . DOI: https://doi.org/10.5038/2325-484X.4.2.1143

Available at: https://digitalcommons.usf.edu/jacaps/vol4/iss2/7

This Article is brought to you for free and open access by the Open Access Journals at Digital Commons @ University of South Florida. It has been accepted for inclusion in Journal of African Conflicts and Peace Studies by an authorized editor of Digital Commons @ University of South Florida. For more information, please contact digitalcommons@usf.edu. 


\section{Introduction}

This paper took a departure from the World Summit in 2005 when Kofi Annan's proposal provided an insight into the creation of peacebuilding architecture. Arising from the plan of the proposal, strategies of peacebuilding were outlined to be useful before communal conflict as peace-making mechanisms and after conflict as peace-keeping techniques (Barnett, Kim, O.Donnell \& Sitea, 2007). The crux of this paper is that, in spite of these peace enhancement strategies, most developing countries in Africa, Asia and Latin America are yet to enjoy longterm, sustained and durable peace (Okoro, 2014; \& MacGinty, 2013). They most often experience serious breakdown of civil order, partisan rejection of constitutional arrangement, severe coup d'etat, civil war, ethnic crisis, political assassinations and political violence of varying degrees. This underlines an assumed gaze between the outlined strategies of peace building as against the practical reality within communities in Africa. It thus becomes important to examine the peace building strategies vis-à-vis their workabilities within the space of African communities.

This paper confined its scope to Nigeria which comprises one of the piloting zones for the masterpiece in Africa. The justification for choosing this Nigerian State will be owing to its proximity and closeness to the researcher as well as the in-depth understanding of the environment and social landscape. It thus underlines a fulcrum for reflections between researcher and his specific region. Specifically in Southwestern Nigeria, protracted conflicts had lasted over a century among chiefdoms and kingdoms on crisis of identity recognition, inter-ethnic rivalry, crisis of inheritance protection and proprietary rights (Oladoyin, 2001, Toriola, 2001, Albert, 2007 \& Enuka, 2008). Despite several foreign aid interventions, these conflicts still persist among communities in these defunct chiefdoms and kingdoms, presently occupying the Southwest geo-political zone of Nigeria. Hence, there is therefore the need to review the workabilities of peace building strategies, and its influence on peace enhancement, by drawing quantitative and qualitative examples from Southwestern Nigeria.

\section{Statement of the Problem: Why this Study?}

In Africa, most communities still suffer communal conflicts despite the outline of peace building strategies which emphasize peace-making and peace-keeping at local level. Furthermore, in Nigeria, just like any other African states, governance crisis still ravages local peace beyond 
description (Adebayo, 2006). Studies have shown that no community is exclusively free from the conflict emanating as a result of chieftaincy matters, indigenes-settlers brawls, land and boundary disputes (Toriola, 2001; Adebanwi, 2004; Enuka, 2008; MacGinty, 2013; \& Olaleye, 2016; Lamidi, 2019c). However, these research outcomes put the efficacy of peace building strategies in question on above-mentioned disputes and brawls within African societies. It therefore becomes important to put the peace building architecture in critical and scientific perspective so as to evaluate the strategies and critical elements for its consistent relevance in enhancing peaceful co-existence in Africa using a convenient scope of Southwestern Nigeria as a case study.

\section{Peace building Strategies in Southwestern Nigeria}

In southwestern Nigeria, customs and traditions are the sources of their indigenous laws, rules, and regulations. The literacy level in this part of African communities was associated with verbal arts and historical antecedents and traditional performances because traditional maxim is largely unwritten (Adam, 2000; \& Kotze, 2000; Lamidi, 2019a). For this reason, the arbitration system in Yoruba land precipitates on traditional knowledge and wisdom as exhibited by their ancestral fathers. Community associations are established and saddled with the responsibility of peace sustenance and order maintenance within the marketplace and age-grade, as well as on land disputes, chieftaincy matters, and all other social problems.

In this region, the strategies of peace building address the notable social interactions among the people. At the family level, this is the smallest unit of a community which is called Idile in Yoruba parlance and the Head of family is called Bale. Ensuing Cases at this level are resolved by Bale which may involve conflicts among sons and daughters, co-wives, fights involving his dependants and their neighbours (Oguntomisin, 2004; \& Nwolise, 2005). The informal strategy here is that the Bale appeases to the disputants and seeks for his acceptance of his peaceful means to the resolution of the conflict. However, the Bale would still sound a warning to his offspring to desist from any trouble-prone action.

At the second level, the extended family encompasses many families which are bounded by blood ties. The extended family is called Ebi in Yoruba parlance, and the Head of extended 
family is called Mojagi. A notable peace enhancement strategy at this level seems to address main issues on inheritance, and any case that threatens the livelihood of the extended family members, marital infidelity, land dispute, as well as control of the relationship between family members and outsiders.

The third level of societal strata is called Adugbo in Yoruba parlance which comprises several family compounds headed by Baale. Conflict issues at this stage are treated as civil cases. The peace building processes are carried out by the court of the ward-chief which is locally called Ileejo ijoye Adugbo (Ajayi \& Buhari, 2014; Lamidi, 2019b). This committee could not adjudicate on criminal cases, but they are seldom charged with the conduct of preliminary investigations into civil cases for onward transmission to the customary courts.

At the last level, towns and cities in Yoruba land have coordinated institutions for peace enhancement. This is a sole responsibility of Chief-in-Council called Igbimo Ilu in Yoruba parlance. This Chief-in-Council was regarded as apex court wherein "appeal could be made but, distinctively in Egba and Ijebu, however, the Ogboni court was the last court of appeal" (Oguntomisin, 2004:11). Despite the strategic arrangement of peace building strategies at most societal strata, the modern quest for peace building does not employ the traditional enlisted mechanism for peace building. Rather, justice is presently being sought through the adjudicative measures bestowed upon the country at independence (Olaoba, 2005; \& Ajayi \& Buahri, 2014). Unlike the inherited colonial resolution system, no fine of damage is being awarded to disputants in the indigenous system. Moreso, the colonial judicial system seeks to identify the culpable one between or among the conflicting parties. Instead, the utmost concern of the local mediators is to amicably settle the civil cases and restore peace between or among the warring groups or communities. This is thus the crux of peace building strategies at the different strata of the Southwestern Nigeria.

However, a broad dimension of peace building strategies came into being in 2005 which was proclaimed to have a more comprehensive capability to subsume conflicts at the respective levels of developing society, Southwestern Nigeria inclusive. It was under the auspices of UN. The UN proposal called for the establishment of three (3) supportive organisations: the UN Peace 
building Commission, which was founded in 2005; the UN Peace building Support Office, which was created in 2005; and the UN Peace building Fund, founded in 2006.

Arising from the formation of the three (3) organisations, UNPBSO specifically outlined the strategies of peace building, mostly practicable by local institutions of governance within local communities. These include: quick response; mediation of differences; cross-examination of disputants; negotiation; reconciliation; transitional justice and restoration (communal adjudication); ethnic cooperation; building bridges between different communities (community dialogue); re-integrating former combatants into civilian society; developing rule of law systems and local governance systems; management of post-conflict local environments; and developing pressure and civil society groups as well as community-based organisations that can represent diverse interests and challenge the governments peacefully (UNPBSO, 2012). Therefore, the missing gap is that these peace building strategies are yet to be evaluated with Southwestern Nigeria. Thus, the simple intent of this study is thus to evaluate the strategies of peace building adopted for the enhancement of peaceful co-existence at the local communities within Southwestern Nigeria. The study would provide relevant information on current dimensions of peace building in Southwestern Nigeria. It would also enhance the knowledge of community leaders and policy makers both at local and international levels on the activities of the local governance institutions towards the enhancement of peaceful co-existence in Yorubaland.

\section{Research Strategy and Methodology}

To achieve the intent of this study, mixed-method analysis was adopted. Quantitative data were collected through the administration of questionnaire. This study was carried out in Southwestern Nigeria, and it was delimited to a manageable scope of 18 Local Government Areas (LGAs) using multi-stage sampling technique. Also, this study covered the period of 2005 to 2017. The choice of this period is because integrated efforts have been on-going to examine the formulated peacebuilding strategies across cultures, thus this study aims to achieve same mission within the Yoruba culture in Africa (Southwestern Nigeria). The study population 2, 479 comprised Local Council Officers (193), Traditional Chiefs (270), executive members of Community Development Associations (540), executive members of Market Women Associations (90) and key executive members of National Union of Road Transport Workers (90), executive officials 
of Christian Association of Nigeria (198) and Muslims' Community (324), executive members of Traditional Associations (108), High chiefs of Hausa community (126) and Igbo community (90) and, Customary Court Chiefs (216) and executive members of Nigerian Bar Associations (234). These respondents were targeted because they are considered to be knowledgeable and at a vantage position to give useful information on the operationalisation of peacebuilding process in the study area. A sample fraction of 10\%, making 248 respondents, was selected for questionnaire administration from the study universe.

In addition, qualitative data was collected through interviews and FGD sessions. Interviews was conducted in the three selected States for each of their Attorneys-General, or their representatives, most especially on the conflict emanating from the political parties; Chairmen of the Nigerian Bar Associations, or their representatives; a Paramount Traditional Ruler in the three States; President, State Muslims' Community of the selected States; Chairman, Christianity Association of Nigeria State Chapter of the three States; and State Leaders of Non-Indigent Groups in the selected States, totaling 21 so as to complement information collected through questionnaire administration. Also, FGD was conveniently conducted among towns with recent conflict occurrence within Osun State: in Ile-Ife, for Peace Reconciliation Committee (PRC) on Indigene-Settlers crisis; in Oba-Oke and Oba-Ile for PRC on Chieftaincy Disputes; as well as, Ipetumodu and Asipa for PRC on Boundary Disputes. In addition, FGD was organized for the members of Ogun State Chieftaincy Tribunal under the auspices of Ogun State Ministry of Local Government and Chieftaincy Affairs. In Ondo State, FGD was also conducted for members of the Ondo State House of Assembly Committee on Peace and Security. Quantitative data collected was analyzed using mean value; while, content analysis and ZY index were used for qualitative responses gathered through interviews and FGD sessions respectively.

\section{Research Instruments: Its Validation/ Reliability}

The instruments to be used in this study were questionnaire, interview and FGD guide. The questionnaire consisted of open and closed-ended questions. Also, interview and FGD guide comprised questions that are capable of generating qualitative data on the dimensional component of peace building towards enhancement of peaceful co-existence at the local level. 
Research instruments were validated using content validity. In this regard, the research instruments, which are questionnaire form, interview and FGD guide, were subjected to inspectoral and logical discourse by the behavioural scientists in this area of specialisation so as to ensure that assertions/statements are evocative to the respondents. In order to ensure the reliability of these research instruments, a preliminary study was conducted to pre-test the questionnaire by administering it on a subset of the study population. The reliability of the instrument was assured by the consistency of the response to the questionnaire. This was derived from the result of test and re-test to find the reliability co-efficient between the results of the test and re-test.

However, the internal consistency approach was utilized to estimate the reliability of the measurement scales for this study; and the most commonly used indicator for this purpose is, the Cronbach's alpha coefficient. Cronbach's alpha $\alpha=0.8$ can be interpreted as a correlation coefficient whose value ranges from 0 to 1 . It is concerned with the degree to which the items that make up a scale are internally consistent with each other. Generally, Cronbach's coefficients that are below 0.6 are poor, above 0.7 are acceptable, while coefficients that are higher than 0.8 are considered good. Thus, the closer the cronbach's coefficients are to 1, the better.

\section{Quantitative Data Analysis}

This section presented quantitative data analysis as well as interpretation of the respondents' views on the adopted peace building strategies for the enhancement of peaceful co-existence at the local level in Southwestern Nigeria. The Table 1 revealed the quantitative data analysis on frequency and percentage distribution of respondents as well as the mean score and standard deviation on each of the assertions set out to evaluate strategies of peace building adopted for the enhancement of peaceful co-existence. Its values/responses were organised using a Likert scale of measurements, such as Very High Extent (5) High Extent (4), No Extent (3), Low Extent (2) and Very Low Extent (1). In addition, the qualitative data would be analysed so as to confirm or balance up the interpretation of the quantitative data analysis. The content of the interview responses would be thematically analysed with clear indicators from the ZY Index used for the FGDs. 
As presented in Table 1, quick intervention is firstly subjected to the evaluative views of respondents as one of the peace building strategies. The respondents were asked to react on the basis of the extent to which quick intervention/response has been adopted for the enhancement of peaceful co-existence. In their reactions to this first assertion, 132 (57.6\%) of the respondents rated the assertion to a very high extent; with a complementary trend of $83(36.2 \%)$ of the respondents rated it to a high extent. About 11 representing $4.8 \%$ of the respondents gave the assertion no rating; while only $3(1.3 \%)$ of the respondents rated the assertion to a low extent. The mean value and standard deviation $\overline{(X}=4.54, \mathrm{SD}=0.623)$ confirmed this frequency distribution. The interpretation of this distribution is that quick response/intervention is a notable peace building strategies adopted for the enhancement of peaceful co-existence in local areas within Southwestern Nigeria.

The second assertion is about the mediation of differences. This strategy did not enjoy much acknowledgement as an adopted peace building mechanism, like that of quick responses. This is because about $20 \%$ of the respondents rated this strategy to a low extent category. Nonetheless, $184(80.3 \%)$ of the respondents rated this second assertion to a high extent. This implies that despite the fact that mediation of differences is an observed peace building strategies in the study area, as evident in the mean value and standard deviation $\overline{(X}=4.25, \mathrm{SD}=0.914)$. Its low rating, however, places an indictment on the expected efficiency of this peace building strategy.

The third assertion in Table 1 sought the respondents to evaluate the extent to which crossexamination of the affected people has brought about identifying facts upon which actions/decisions could be taken for sustaining durable peace in local areas. In their responses, 195 representing $85.2 \%$ of the respondents rated this assertion to the high extent. However, an approximate of $10 \%$ of the respondents chose no extent to this assertion, just $12(5.3 \%)$ of the respondents rated it low. In spite of this poor scoring, there is a wide gap in the number of respondents who rated the assertion to be high, when comparing to the low category. This indicates that cross-examination of conflictual people, among other issues, was acknowledged to be a common peace building strategy adopted towards the enhancement of peaceful co-existence in local areas. This finding was further confirmed by the mean value and standard deviation $\overline{(X}$ $=4.26, \mathrm{SD}=0.855)$ as it tended towards agreement with the statement. 
In respect to the fourth assertion presented in Table 1, negotiation was evaluated as one of the prominent peace building strategies for the enhancement of peace building strategies. The descriptive statistics revealed that $97(42.4 \%)$ of the respondents rated the assertion to a very high extent and $96(41.9 \%)$ of the respondents rated to an ordinary high extent. There was no remark from $17(7.4 \%)$ of the respondents. However, $19(8.3 \%)$ of the respondents rated the assertion to a low category. The implication of this data distribution is that negotiation remains a prominent strategy of peace building adopted for the enhancement of peaceful co-existence in local communities within Southwestern Nigeria $\overline{(X}=4.23, \mathrm{SD}=0.923)$.

On the fifth assertion in Table 1, it was also asserted that peace building strategies have, to which extent, emphasized reconciliation of intra and inter-conflict groups and communities in your area. Reacting to this, respondents' frequency appeared very high in low rating category, as 117 $(51.1 \%)$ of the respondents rated this assertion to a low extent, as against $106(46.2 \%)$ of the respondents who rated this assertion to a high extent. These descriptive statistics showed a ratio output of 5:4:1 on every 10 individuals' opinions on peace building and intra or inter-conflict group reconciliation. This further interprets that out of every 10 respondents: 5 respondents rated the assertion low; 4 respondents rated it high, and 1 respondent tended to be indifferent on this assertion. It thus indicates that peace building strategies are, though to a low extent, feasible in the resolution of all forms of conflicts within the study area $\overline{(X}=2.98, \mathrm{SD}=1.824)$.

With regards to the sixth assertion, $163(71.2 \%)$ rated to a high extent and $40(17.4 \%)$ rated to a low extent that adjudication of communal conflicts has the capability of enhancing peaceful coexistence among concerned individuals, groups, and communities in your locality. Nonetheless, 26 representing $11.4 \%$ of the respondents gave the assertion no extent rating. This finding indicated that the local means of adjudication has no limited capacity towards the enhancement process of peaceful co-existence among the constituent unity in communities with Southwestern Nigeria $\overline{(X}=3.85, S D=1.147)$. This however represents one of the cardinal responsibilities of traditional chiefs in the system of local governance. 
On the seventh assertion in Table 1, ethnic cooperation suffers a major neglect and poor rating as a peace building strategy adopted for the enhancement of peaceful co-existence in local areas within Southwestern Nigeria. This was observed from the reactions of the respondents as 123 $(53.7 \%)$ rated this strategy to a very low extent and $72(31.4 \%)$ rated the strategy to a low extent. On aggregate, $195(85.1 \%)$ of the respondents rated the strategy to a low category, as against just $32(14 \%)$ of the respondents who rated it to a high extent. This is rather an empirical confirmation to the common saying that Yoruba kingdoms and chiefdoms lack both intra and inter-ethnic cooperation thereby giving rooms to all sorts of communal conflicts in the local communities of Southwestern Nigeria. This result is confirmed by $\overline{(X}=2.35, \mathrm{SD}=1.978)$ which falls below the mid-point of 3.0 .

As shown by the eighth assertion in Table 1, 175 (76.5\%) of the respondents rated to a high extent that community dialogue has helped in the enhancement of peaceful co-existence in respective localities within Southwestern Nigeria. However, 18 (7.9\%) of the respondents made no remark; while 34 about $15 \%$ of the respondents rated this strategy to a low extent. This implies that community dialogue is a practical strategy of peace building adopted for the enhancement of peaceful co-existence in local areas within Southwestern Nigeria $\bar{X}=3.99, \mathrm{SD}=$ 1.203). The representative nature of local institution was also set out for evaluation as one of the possible strategies adopted for enhancement of peaceful co-existence at local areas in the study zones. Remarkably, on this ninth assertion, 156 (68.1\%) of the respondents recognised, to a high extent, that local institutions have developed civil societies that can represent diverse interests of the community members. However, this representativeness seems not to be commanding marked recognition, as $34(14.8 \%)$ of the respondents gave no rating scale and $38(16.6 \%)$ of the respondents rated this strategy to a low extent. This data distribution shows that the role of local institutions is mere identifiable peace building strategy adopted for the enhancement of peaceful co-existence in local communities $\overline{(X}=3.79, \mathrm{SD}=1.250)$. This also affirms the local institutions as first-point of contact to all communal conflicts.

With respect to the tenth assertion in Table 1, $155(67.7 \%)$ of the respondents scaled to a high extent the assertion that legal system has provided an avenue for transitional justice and restoration across conflictual parties in your local area. This result was not a mere guess because 
its mean value and standard deviation $\bar{X}=3.78, \mathrm{SD}=1.235)$ indicated that more respondents rated this assertion towards high extent. This is also a revelation that any unresolvable communal conflict often transited to the legal arena for transitional justice so as to restore executive peace and order in the concerned areas.

The last assertion in Table 1 stated that peace building strategies have, to which extent, emphasized the rehabilitation of a post-conflict society's ability towards promotion of socioeconomic development. Responding to this assertion, $76.9 \%$ of the respondents rated this assertion to a high extent which was far more than those on the low extent $(10.1 \%)$. This is, therefore, an indication that peace building strategies are observable trends in the enhancement of peaceful co-existence with mean value and standard deviation $\overline{(X}=3.45, \mathrm{SD}=1.122)$.

Table 1: Evaluation of Peace Building Strategies Adopted for the Enhancement of Peaceful Co-Existence at the Local Level

\begin{tabular}{|c|c|c|c|c|c|c|c|c|}
\hline \multirow[b]{2}{*}{ Assertions } & \multirow{2}{*}{$\begin{array}{c}\begin{array}{c}\text { Very } \\
\text { High } \\
\text { Extent }\end{array} \\
f \\
(\%) \\
\end{array}$} & \multirow{2}{*}{$\begin{array}{c}\text { High } \\
\text { Extent } \\
\mathrm{f} \\
(\%)\end{array}$} & \multirow{2}{*}{$\begin{array}{c}\begin{array}{c}\text { No } \\
\text { Extent }\end{array} \\
f \\
(\%)\end{array}$} & \multirow{2}{*}{$\begin{array}{c}\text { Low } \\
\text { Extent }\end{array}$} & \multirow{2}{*}{$\begin{array}{c}\begin{array}{c}\text { Very Low } \\
\text { Extent }\end{array} \\
\mathrm{f} \\
(\%)\end{array}$} & \multirow{2}{*}{$\begin{array}{c}\text { No } \\
\text { Response } \\
f \\
(\%)\end{array}$} & \multicolumn{2}{|c|}{$\begin{array}{l}\text { Descriptive } \\
\text { Statistics } \\
\text { N=229 }\end{array}$} \\
\hline & & & & & & & $\begin{array}{l}\text { Mean } \\
\text { Value }\end{array}$ & \begin{tabular}{c|} 
Standard \\
Deviation
\end{tabular} \\
\hline $\begin{array}{l}\text { 1. Quick response/intervention could, to } \\
\text { what extent, enhance the peaceful co- } \\
\text { existence among conflicting individuals, } \\
\text { groups and communities in your local area }\end{array}$ & $\begin{array}{c}132 \\
(57.6)\end{array}$ & $\begin{array}{c}83 \\
(36.2)\end{array}$ & $\begin{array}{c}11 \\
(4.8)\end{array}$ & $\begin{array}{c}3 \\
(1.3)\end{array}$ & $\begin{array}{l}- \\
(-)\end{array}$ & $\begin{array}{l}- \\
(-)\end{array}$ & 4.54 & .623 \\
\hline $\begin{array}{l}\text { 2. Mediation of differences goes, to which } \\
\text { extent, in harmonising peaceful relationship } \\
\text { among concerned individuals, groups, and } \\
\text { communities }\end{array}$ & $\begin{array}{c}107 \\
(46.7)\end{array}$ & $\begin{array}{c}77 \\
(33.6)\end{array}$ & $\begin{array}{c}24 \\
(10.5)\end{array}$ & $\begin{array}{c}21 \\
(9.2)\end{array}$ & $\begin{array}{l}- \\
(-)\end{array}$ & $\begin{array}{l}- \\
(-)\end{array}$ & 4.25 & .914 \\
\hline \begin{tabular}{|l} 
3. Cross-examination of affected people \\
has, to what extent, brought about \\
identifying facts upon which \\
actions/decisions could be taken for \\
sustaining durable peace in your local area
\end{tabular} & $\begin{array}{c}103 \\
(45.0)\end{array}$ & $\begin{array}{c}92 \\
(40.2)\end{array}$ & $\begin{array}{c}22 \\
(9.6)\end{array}$ & $\begin{array}{c}10 \\
(4.4)\end{array}$ & $\begin{array}{c}2 \\
(0.9)\end{array}$ & $\begin{array}{l}- \\
(-)\end{array}$ & 4.26 & .855 \\
\hline $\begin{array}{l}\text { 4. Negotiation, as one of the prominent } \\
\text { peace building strategies, has a particular } \\
\text { extent in the enhancement of peaceful co- } \\
\text { existence in your community }\end{array}$ & $\begin{array}{c}97 \\
(42.4)\end{array}$ & $\begin{array}{c}96 \\
(41.9)\end{array}$ & $\begin{array}{c}17 \\
(7.4)\end{array}$ & $\begin{array}{c}16 \\
(7.0)\end{array}$ & $\begin{array}{c}3 \\
(1.3)\end{array}$ & $\begin{array}{c}- \\
(-)\end{array}$ & 4.23 & .923 \\
\hline $\begin{array}{l}\text { 5. Peace building strategies have, to which } \\
\text { extent, emphasized reconciliation of intra } \\
\text { and inter-conflict groups and communities } \\
\text { in your area }\end{array}$ & $\begin{array}{c}83 \\
(36.2)\end{array}$ & $\begin{array}{c}23 \\
(10.0)\end{array}$ & $\begin{array}{c}4 \\
(1.7)\end{array}$ & $\begin{array}{c}100 \\
(43.7)\end{array}$ & $\begin{array}{c}17 \\
(7.4)\end{array}$ & $\begin{array}{c}2 \\
(0.9)\end{array}$ & 2.98 & 1.824 \\
\hline $\begin{array}{l}\text { 6. Adjudication of communal conflicts has, } \\
\text { to which extent, the capability of enhancing } \\
\text { peaceful co-existence among concerned } \\
\text { individuals, groups, and communities in } \\
\text { your locality }\end{array}$ & $\begin{array}{c}82 \\
(35.8)\end{array}$ & $\begin{array}{c}81 \\
(35.4)\end{array}$ & $\begin{array}{c}26 \\
(11.4)\end{array}$ & $\begin{array}{c}34 \\
(14.8)\end{array}$ & $\begin{array}{c}6 \\
(2.6)\end{array}$ & $\begin{array}{l}- \\
(-)\end{array}$ & 3.85 & 1.147 \\
\hline
\end{tabular}




\begin{tabular}{|c|c|c|c|c|c|c|c|c|}
\hline $\begin{array}{l}\text { 7. As a peace building strategy, ethnic } \\
\text { cooperation could, to what extent, facilitate } \\
\text { the peaceful relationship between indigenes } \\
\text { and settlers }\end{array}$ & $\begin{array}{c}15 \\
(6.6)\end{array}$ & $\begin{array}{c}17 \\
(7.4)\end{array}$ & $\begin{array}{c}- \\
(-)\end{array}$ & $\begin{array}{c}72 \\
(31.4)\end{array}$ & $\begin{array}{c}123 \\
(53.7)\end{array}$ & $\begin{array}{c}2 \\
(0.9)\end{array}$ & 2.35 & 1.978 \\
\hline $\begin{array}{l}\text { 8. Community dialogue has, to which } \\
\text { extent, helped in the enhancement of } \\
\text { peaceful co-existence in your locality }\end{array}$ & $\begin{array}{c}101 \\
(44.1)\end{array}$ & $\begin{array}{c}74 \\
(32.3)\end{array}$ & $\begin{array}{c}18 \\
(7.9)\end{array}$ & $\begin{array}{c}24 \\
(10.5)\end{array}$ & $\begin{array}{c}10 \\
(4.4)\end{array}$ & $\begin{array}{c}2 \\
(0.9)\end{array}$ & 3.99 & 1.203 \\
\hline $\begin{array}{l}\text { 9. Local institutions have, to what extent, } \\
\text { developed civil societies that can represent } \\
\text { diverse interests of the community } \\
\text { members }\end{array}$ & $\begin{array}{c}87 \\
(38.0)\end{array}$ & $\begin{array}{c}69 \\
(30.1)\end{array}$ & $\begin{array}{c}34 \\
(14.8)\end{array}$ & $\begin{array}{c}30 \\
(13.1)\end{array}$ & $\begin{array}{c}8 \\
(3.5)\end{array}$ & $\begin{array}{c}1 \\
(0.4)\end{array}$ & 3.79 & 1.250 \\
\hline $\begin{array}{l}\text { 10The legal system has, to what extent, } \\
\text { provided an avenue for transitional justice } \\
\text { and restoration across conflictual parties in } \\
\text { your local area }\end{array}$ & $\begin{array}{c}81 \\
(35.4)\end{array}$ & $\begin{array}{c}74 \\
(32.3)\end{array}$ & $\begin{array}{c}30 \\
(13.1)\end{array}$ & $\begin{array}{c}34 \\
(14.8)\end{array}$ & $\begin{array}{c}10 \\
(4.4)\end{array}$ & $\begin{array}{c}- \\
(-)\end{array}$ & 3.78 & 1.235 \\
\hline $\begin{array}{l}\text { 11. Peace building strategies have, to which } \\
\text { extent, emphasized the rehabilitation of a } \\
\text { post-conflict society's ability towards } \\
\text { promotion of socio-economic development }\end{array}$ & $\begin{array}{c}84 \\
(36.7)\end{array}$ & $\begin{array}{c}92 \\
(40.2)\end{array}$ & $\begin{array}{c}30 \\
(13.1)\end{array}$ & $\begin{array}{c}18 \\
(7.9)\end{array}$ & $\begin{array}{c}5 \\
(2.2)\end{array}$ & $\begin{array}{c}- \\
(-)\end{array}$ & 3.45 & 1.122 \\
\hline
\end{tabular}

Source: Field Survey, 2018.

NB: $f=$ Frequency; $\%=$ Percentage

\section{Qualitative Data Analysis}

On the other hand, the quantitative outcomes were complemented with the qualitative responses from the in-depth interview and FGDs. A cross-section of interviewees asserted that the strategies of peace building are much more than the enlisted peace building strategies by the International agencies. It is emphasized to be multi-dimensional; and, sometimes it takes its course based on the dynamic nature of conflict occurrence. According to one of the AttorneysGeneral, he noted that "peace building is everybody business". To him, it is geared towards ensuring the absence of all forms of violence in the community. It is not a sole responsibility of either legal or security agencies or both. Rather, many responsibilities are expected from the populace. It was asserted by some interviewees that the strategies of peace building are not alien to the Yoruba nation; though the strategies are not conceptually projected so as to gain ground in other tribes across the globe.

Notably, two representatives of NBA chairmen in Ogun and Ondo states maintained that civic culture and public enlightenment are another set of factors that could enhance peaceful coexistence in the local communities. As observed by some traditional rulers, community members understand what the possible gain is in a peaceful environment; thus no one would want to infringe upon another person's right. To this end, community sensitisation was a notable strategy 
mostly used by local unions to enhance peaceful co-existence; and even dissemination of information to the security agencies to nip in the bud any form of the violent act which could obstruct the peaceful environment.

A paramount traditional ruler maintained that peace enhancement is an important quest in all communities. There are traditional structures established in pursuance of this communal requisite. Interviewees noted that the traditional structures are hierarchical vis-à-vis the societal strata in each of the local communities in Southwestern Nigeria. Notably, the structure of Ife Kingdom exemplified this traditional setting as the cradle of Yoruba race. A traditional ruler in the Ife Kingdom advanced further on this position that the Baale holds a strategic position in making resolution of conflicts within the extended families making up a compound. However, in a settlement consisting of several compounds, a traditional association, called Ajo, is put in place to mediate differences or conflicts within the settlement. After this stratum, there is a local group called "Emese" known as the emissaries. This group is concerned with the resolution of disputes on land and chieftaincy matters. The group also resolves conflicts that could not be resolved by the two (2) former institutions, and serves as interlink between the people and the Royal Majesty. The traditional chiefs, however, assist the Royal majesty in the adjudication of cases. This Ife traditional structure is a similitude of all indigenous structures within towns in the Yoruba nation.

The traditional structures exhibit almost similar strategies with the outlined ones in the legal system. Although, the traditional strategies are not totally legalised; thus they sometimes do not enjoy citizens' legitimacy. But a remarkable leverage of these strategies is proper consultation: which is a peace building strategy usually adopted within the Yoruba culture. This was further argued by a representative of a NBA State Chapter that, in fact, the traditional peace building architecture was presumably built upon in a bid to design the modern peace building architectural strategy. He said:

The colonialists understudied the traditional judicial system, and metamorphosed it to customary courts using the same existing traditional structures. In fact, judiciary recognises the traditional adjudicating setting because it looks for the truth not suitability in arguments. 
The traditional setting does not interfere with legal rulings.

Furthermore, historical antecedents are other veritable strategies of peace building for the enhancement of peaceful co-existence, especially on land and chieftaincy disputes at the local areas in Southwestern Nigeria. Buttressing this assertion, a High Chief, representing one of the paramount traditional rulers in Ogun state, averred that "no strategy can best resolve chieftaincy disputes than historical dynasty. In Yoruba culture, it is the history that will give us information as to what your lineage position is in the community. And no one will be able to lay claim to what does not belong to his/her lineage." To this end, historical antecedents and dynasty are distinctive strategies of peace building usually adopted for the enhancement of peaceful coexistence on chieftaincy and land matters as well as the indigenes-settlers crisis in local communities within Southwestern Nigeria.

Most of the non-indigenous group leaders maintained that community dialogue is a commonly used strategy to facilitate peaceful co-existence. One of the leaders, however, noted that sign of discrimination, most times, hinders this strategy. Meanwhile, the religious leaders significantly emphasized the gospel teaching of 'love thy neighbours like yourself' as a means of enhancing peaceful co-existence with faith in God as its strong basis. This strategy is said to be efficacious on ensuing religious as well as indigenes-settlers' crises. A pastor stressed that "follow peace with all men or with holiness without which no man shall see the Lord" and "do not pay evil with evil, let your good overtakes the evil" (Roman 12: 17-21). Also, one of the Islamic clerics in Ondo State explained a verse in the Qur'an which reads "O ye who believe! Persevere in patience and constancy; vie in such perseverance; strengthen each other and fear Allah: that ye may prosper" (Qur' an 3 Vs. 200). Summarily, the interview response revealed community sensitisation, proper consultation, historical antecedents and dynasty, community dialogue as well as gospel teaching as qualitative strategies of peace building usually adopted for the enhancement of peaceful co-existence in Southwestern Nigeria

In furtherance of the interview response, the FGD sessions were conducted across selected towns with recent conflict occurrence and peace building experience. The recorded tapes were transcribed and compared with the note taken for validation. Possible errors and omissions were 
corrected and coded under different themes using note $(-,+$, and ++$)$. The interpretation of these signals is annotated below the ZY Index Table.

According to the findings shown in ZY Index Table 2, many of the discussants in the three (3) States were aware of quick intervention, cross-examination of disputants, negotiation, mediation of differences, ethnic cooperation, community dialogue, community sensitisation, proper consultation, historical dynasty and antecedents, as well as gospel teaching as strategies of peace building for the enhancement of peaceful co-existence at local areas in Southwestern Nigeria. Most members of PRC in Osun state maintained dual positive on historical dynasty and antecedents. This expression was somewhat remarkable across the board. In the same vein, gospel teaching accorded few credits by the discussants.

While few in Ogun state noted that proper consultation is a major strategy of peace building on the ensuing Chieftaincy crisis. Mediation of differences is known by many discussants in Ogun and Osun States especially on the indigenes-settlers crisis. Across the three (3) States, most of the discussants relegated ethnic cooperation as a strategy of peace building owing to its unfeasibility. There was a strong acknowledgement by all the discussants in the three (3) States that quick intervention, proper consultation, and frequent community dialogue are main strategies of peace building on land/boundary disputes and indigenes-settlers' crisis in Southwestern Nigeria.

Table 2: Peace Building Strategies in Southwestern Nigeria (ZY Index)

\begin{tabular}{|l|c|c|c|}
\hline \multicolumn{1}{|c|}{ Items } & $\begin{array}{c}\text { Ogun } \\
\text { State }\end{array}$ & Osun State & $\begin{array}{c}\text { Ondo } \\
\text { State }\end{array}$ \\
\hline Quick Intervention & ++ & ++ & ++ \\
\hline Cross-Examination of Disputants & ++ & + & + \\
\hline Negotiation & + & - & + \\
\hline Mediation of Differences & ++ & ++ & + \\
\hline Ethnic Cooperation & - & - & - \\
\hline Community Dialogue & ++ & + & ++ \\
\hline Community Sensitisation & + & - & - \\
\hline
\end{tabular}




\begin{tabular}{|l|c|c|c|}
\hline Proper Consultation & ++ & ++ & ++ \\
\hline Historical Antecedents and Dynasty & + & ++ & + \\
\hline Gospel Teaching & + & + & + \\
\hline
\end{tabular}

SOURCE: Field Work, FGD, 2018

Note: - $\quad$ Negative opinion expressed by more than 12 discussants

$+\quad$ Positive opinion expressed by few or not more than 5 discussants

$+\quad$ Positive opinion expressed by many or at least 10 discussants

\section{Discussion of Findings}

This section provided supplementary discussion on both quantitative and qualitative analyses. It further synchronised the findings with related existing studies on the subject matter. However, it attested to the divergence views between the study findings and existing literature. As noted in the findings on objective one, $94 \%$ of the respondents acknowledged quick intervention as a strategy of peace building. This finding would, indeed, remain strategic because it can capture a common cause of communal conflict, as identified by Folami and Olaiya in 2015, which is high insensitivity to psycho-social and economic needs of conflicting individuals, groups and communities. The quick intervention thus facilitates proper understanding of the communal conflict; raises high sensitivity of local institutions of governance on intricacies of the crisis; and helps in prompt subduing of the conflict. These represent the starting point of peace building strategies across cultures. Proper consultation, as noted in the interview response, serves as the instrumentality of this strategy. This enjoyed strong acknowledgement by discussants in FGD sessions. Hence, quick intervention becomes purposive; since it is aimed at meeting/consulting the concerned individuals, groups and communities on the conflictual issues.

Dawon (2004) conducted a study of peace enhancement strategy within Beti society in Cameroon. He, however, revealed that one of the peace enhancement methods is to provide an avenue for cross-examining troublemakers. As laudable as it is in Cameroon, so also in Nigeria when about $85 \%$ of the respondents to this study rated cross-examination of disputants to a high extent as peace building strategy for peace enhancement. Furthermore, Ajayi and Buhari (2014) attempted to categorise the action lines of peace building strategies across cultures in Africa. 
They however ascertained cross-examination of disputants as a frontline of actions for peace building processes. Ademowo (2015) concretised this position that all flourishing peace building processes require the awareness and consent of disputants which is at best achieved through cross-examination. Without this strategy, it becomes somewhat impossible to persuade and convince the individual or group disputants about the implications of the communal conflict. From the qualitative response, this cross-examination synergises community dialogue. Also, historical dynasty and antecedents serve as guiding principles and reference points for the discussion during the course of cross-examination of disputants on communal conflict.

Extant studies have posited that negotiation is an operational strategy of peace building mechanism which induces combatants to peace dialogue (Dawson, 2004; Cannon, 2009; \& Noll, 2013). This study affirmed the cross-sectional position with about $84 \%$ of the respondents placing high extent rating on negotiation as a veritable strategy of peace building for the enhancement of peaceful co-existence. However, the interview response examined this strategy on the communal conflict. It was then argued that negotiation may seem to be ineffective on chieftaincy affairs because the historical dynasty can not be negotiated when adjudicating or resolving chieftaincy matter. This is because what belongs to hunter's compound, since time immemorial, can not be canvassed by the farmer's compound. It is strict senso; unless among the same subjects. Also, a cross-section of the discussants argued the efficacy of this strategy among the constituent local authorities is owing to its highly needed requisite skills of legal, customary and socio-economic intelligences. It is however insightful as this study has clarified its inefficient character on chieftaincy affair. Nonetheless, this finding is still in line with Isiaq (2012) who maintained that negotiation would significantly facilitate peace agreement on land and boundary disputes.

From the quantitative analysis, mediation of differences is another key strategy of peace building for the enhancement of peaceful co-existence at the local level. This is not an astonishing outcome because the UN offices had, since 2005, enlisted mediation of differences as one of the most practicable strategies of peace building at the local level. This however confirms the authenticity of this strategy of peace building. Miller and King (2005) further extolled the virtue of mediation of differences when they argued that human co-existence is vulnerable to fear and mistrust. They posited that mediation of differences is a worthwhile antidote to communal 
adversary, rumour, suspicion and misapprehension. It is a strategic act which can provide peaceful tools for positive change. Ojiji (2007) narrated that community leaders and elder statesmen always play mediation role in communal conflicts across cultures in Africa. Furthermore, the qualitative response also revealed gospel teachings and dictates as 'respected' instruments for mediation of differences. This is because there is a strong divine affinity and belief in God among people in Yoruba culture. This position was also verified by a member of PRC in Osun state that at the end of every mediation processes, the local chiefs will use God, in any faith or belief, to appease the disputants.

\section{Concluding Remarks}

This study revealed that quick intervention (93.8\%), cross-examination of disputants (85.2\%), negotiation $(84.3 \%)$ and mediation of differences $(80.3 \%)$ were evaluated to be the key peace building strategies adopted for the enhancement of peaceful co-existence in local areas within Southwestern Nigeria. However, community sensitisation, proper consultation, historical antecedents and dynasty, community dialogue as well as gospel teaching were exclusive strategies for enhancement of peaceful co-existence in the study area. These strategies were revealed from the qualitative data, and they are not part of the enlisted peace building strategies by the International agencies.

Nevertheless, the paper affirmed the strength of each of the peace building strategies; out of which ethnic cooperation was poorly rated as a strategy. The poor nature of ethnic cooperation underlines the causal reason for incessant communal conflict in Southwestern Nigeria, among other African communities. To this end, local institutions in Africa should understand their environments and tasks on the lingering crisis. No room should be given for solitary approach rather high emphasis should be placed upon integrative mechanisms across the individuals, groups, and communities. 


\section{References}

Adam, A. M. (2000). Inter-group Conflicts and Customary Mediation: Experience from Sudan in Africa. Journal on Conflict resolution, Vol.2, No.2, p.13

Adebanwi, W (2004) "Democracy and Violence in Nigeria: The Challenge of Communal Clashes" in Adigun Agbaje et al (eds) Nigeria's Struggle for Democracy and Good Governance: A Festschrift for Oyeleye Oyediran. Ibadan: University Press

Adebayo, A. (2006), "Ethnic Conflicts and Nigerian's Democracy and Development (19992004)" in S. Hassan et'al (eds) Democracy and Development in Nigeria (Vol. 3), Social Issues \& External Relations, Lagos. Concept Publication Limited.

Ademowo, Y. (2015). Peace and Conflict Resolution. Being a Lecture Note: Peacemaking in Traditional African Society. National Open University of Nigeria

Ajayi, A. T. \& Buhari, L. O. (2014). Methods of Conflict Resolution in African Traditional Society. African Research Review, Vol. 8 (2) Serial No. 33, p. 138-157

Albert, I. O. (2007). "Concepts and Methods in Peace and Conflict Studies", in C. Bassey \& O. Oshita (Eds.), Conflict Resolution, Identity Crisis and Development in Africa. Lagos, Nigeria: Malthouse Press

Asiyanbola, A. R. (2007). Urban-Ethno Communal Conflict in Africa: Nigeria. A paper submitted for presentation at the Union for Africa Population Studies (UAPS) Fifth African Population Conference, Arusha.

Barnett, M., Kim, H., Donnel, M. \& Sitea, L. (2007). Peacebuilding: What is in a Name? Global Governance 13:1 pp 36, 53.

Cannon, I. R. (2009). Overview of Peacemaking Circles. Cambridge: Cambridge University Press

Dawson, G. (2004). Peacekeeping, Peacebuilding and Peacemaking: Concepts, Complications and Canadian's Role. Canada: Parliamentary Research Branch

Enuka, P. P. (2008). Teaching Community Development to Social Work Students: A Critical Reflection. Community Development Journal, Vol. 10 (2), pp 27-34

Folami, O. M. \& Olaiya, T. A. (2015). Gender, Storytelling and Peace Construction in a Divided Society: A Case Study of the Ife/Modakeke Conflict. Cogent Social Sciences, Vol. 2, pp 1159015

Gamson, W. A. \& Modigliani, A. (1963). Tensions and Concessions: The Empirical Confirmation of Belief Systems about Soviet Behaviour. Social Problems, Vol.11, No.1, p 37-38.

Gamson, W. A. (1992). Talking Politics. Cambridge: Cambridge University Press 
Kotze, Dirk (2000). Issues in Conflict Resolution. African Journal on Conflict Resolution, Vol.12, No.2, p.77-86.

Lamidi, K. O. (2019a). Peacebuilding: Conceptual, Trajectory and Imperative Analyses in the Third World Countries. Canadian Social Science, 15(2), 53 - 64

Lamidi, K. O. (2019b). Challenges of Local Governance Institutions on Peacebuilding in Africa: Empirical Insights from Southwestern Nigeria. Global Journal of Social Sciences. Calabar, Nigeria. 18(1), 95 - 106

Lamidi, K. O. (2019c). "Communal Conflict, Communal Peacemaking and Governmental Interventions: Lessons from the Ife-Modakeke Crisis." African Journal on Conflict Resolution, 19(2): 11-32

Lamidi, K. O. 2020. Localism and Peacebuilding Mechanisms in African Countries. Peace Studies Journal, 13(2), 10 - 28

Miller, C. E. \& King, M. E. (2005). A Glossary of Terms and Concepts in Peace and Conflict Studies. Second Edition. Geneva, Switzerland: University for Peace

Noll, D. (2013). What is Peacemaking? Toronto : Centre for Urban and Community Studies

Nwosile O. B. (ed.) (2005). Traditional Models of Bargaining and Conflict Resolution in Africa: Perspective on Peace and Conflict in Africa. Ibadan: John Archers Ltd.,

Oguntomisin, G. O. (2004). The Processes of Peacekeeping and Peacemaking in Pre-Colonial Nigeria. Ibadan: John Archers

Ojiji, O. (2007). "Conflict Handling Styles" in C. Bassey \& O. Oshita (eds.) Conflict Resolution, Identity Crisis and Development in Africa. Lagos, Nigeria: Malthouse Press

Okoro, E. I. (2014). Conflict Assessment and Peacebuilding Planning in Developing Countries. Senegal: Dakar Press

Oladoyin, A. M. (2001). State and Ethno-communal Violence in Nigeria: The Case of IfeModakeke. African Development, Vol. 26, p. 195-223.

Olaleye, I. O. (2016). Traditional Institutions and Conflict Management in Ekiti State. Being a Thesis Submitted to the Department of Public Administration, Faculty of Administration, in Partial Fulfilment of the Requirements for the Award of Master of Science (M. Sc.) Degree in Public Administration, Obafemi Awolowo University, IleIfe, Nigeria

Olaoba, O. B. (2005). "Ancestral Focus and the process of conflict resolution in Traditional African societies", I. O. Albert (ed.) Perspectives on Peace and Conflict in Africa in Essays in Honour of General (Dr) Abdul Salam A, Abubakar. Ibadan: John Archers Ltd.

Omoleke, I. I. \& Olaiya, T. A. (2015). Democratisation Process and Governance Crisis in Contemporary Nigeria: A Re-examination. African Journal of Political Science and International Relations. Vol. 9 (4), pp $131-140$ 
Sanz, E. \& Tomlinson, J. (2012). The Peacebuilding Story. A Presented at the CPCS Peace Practitioners' Research Conference.

Toriola, O. J. (2001). The Ife-Modakeke Crisis: An Insider View. Ife Psychologi, A9, 21-29. 